\title{
A mid-seventeeth century defence of Galenism
}

This rare little book' provides an opportunity to discuss one of the major medical disputes of early modern times, that between the physicians who belonged to the Galenic school of practice and those who followed the precepts of the 'chemical doctors', the iatrochemists. The book is presented as a 'disputation' held at the Faculté de Médecine in Paris on 'Thursday morning, 2nd April under the presidency of Master Charles Guillemeau, Doctor of Medicine of the Faculté de Paris' at which the question for debate was: La Methode d'Hippocrate est-elle la plus certaine, la plus seure, \& la plus excellente de toutes à guarir les maladies? Is the Hippocratic method the most certain, safe and excellent of all ways of treating diseases?

At the end of the main text we find: ' $A$ ces theses respondra Jean-Baptiste MOREAU, Parisien...' so it would seem that the text is Moreau's thesis (probably for the degree of Doctor of Medicine), set in the form of a question, as was usual. A Latin version of the thesis exists and it is that which would have been presented to the Faculté. Moreau was apparently the author of the main text and, probably, of the eleven 'observations' which follow it, expanding on some topics. Someone, perhaps Moreau himself, must have felt that the thesis was of sufficient public interest to publish a vernacular version. Charles Guillemeau was the son of surgeon Jacques Guillemeau. Born in 1588, he qualified in medicine in Paris in 1626 and was Doyen (Dean) of the Faculté de Médecine in 1634 and 1635; in 1648 he would have been a senior member of the Faculté. Nothing more seems to be known of Jean-Baptiste Moreau.

\section{MOREAU'S THESIS}

The thesis is a vituperative attack on all who do not follow the Galenic school. Beginning by saying that Hippocrates was the best of men and the best of all doctors of all times, it admits that his meaning was often obscure until Galen explained his principles and set them out in a form which has provided the framework of all sound medicine since. All those who do not accept this doctrine are ignorants, charlatans, profiteers, and a danger to the populace. And the worst of them are the pestilential crew of chemical doctors who not only prey on the ignorance of their patients but also poison them with their toxic remedies of which antimony is a prime - but by no means the only - example. The opinions of the iatrochemists are not explained except where an 'explanation' is a hook on which to hang further ridicule and invective. The observations expand on some of the topics which the author finds most repulsive such as the use of antimony, of laudanum to replace opium which is in any case so very dangerous that it should scarcely ever be used - unicorn horn, precious stones, bezoar and the supposed universal antidote 'mithridate'; all are useless, some are also deadly. It is implicit that the iatrochemists were purveyors of all of these. The diatribe extends over 94 pages and was probably music to the ears of many of the Faculté on that April morning in 1648. But why is this outpouring of invective and ridicule of any interest? In what follows I have drawn on Debus ${ }^{2}$ and Trevor-Roper ${ }^{3}$ where much more detail will be found.

\section{GALENIC PHYSICIANS VERSUS 'CHEMICAL DOCTORS'}

Under the guise of a question about the pre-eminence of the Hippocratic method, the thesis presents a version of one side of a bitter quarrel which raged over more than a century and in several countries. It was most bitter in Paris where one of its manifestations was the 'antimony wars' between 1566 and 1666; in 1566 the Faculté first condemned the therapeutic use of antimony, in 1637 it added it to its newly drawn up 'livre de medicamens' (pharmacopoeia) but did not approve its use, and finally in 1666 its use in therapeutics was approved. ${ }^{4}$ In 1556 and 1666 the Faculté's resolution was confirmed by edict of the Parlement of Paris. But the case of antimony was only the most celebrated symptom of the quarrel.

The roots of the two opposing views lie in the results of two sets of events, the influx from the East after the mid-fifteenth century of 'new' ancient texts previously unknown in the West - or known only in incomplete and corrupt versions - and the religious upheavals that followed Martin Luther's attack on the Church, the Reformation, whose overt beginning can be placed 
around 1520.These events resulted in a huge outpouring of texts which, thanks to the development and rapidlyincreasing prevalence of printing, exerted their influences more widely and much more rapidly than would have been possible earlier.

Rather late in the flood of ancient texts that had begun in the previous century came Greek texts of the Hippocratic school of medicine - generally assumed in the Renaissance to be the works of a single physician, Hippocrates of Kos - and various works by the 'Greek' physician and surgeon Galen who worked and wrote in Rome in the second century AD. Hippocrates and Galen were, of course, famous in the West much earlier but the new texts, particularly Galen's, added greatly to the quantity and, particularly, to the accuracy of knowledge of ancient medical practice. Knowledge of Greek in Europe in the late fifteenth and early sixteenth centuries was not common but the influx of these new texts proved a powerful stimulus to revival of its teaching and learning. Best known now as writers on anatomy, Guinter von Andernach and lacobus Sylvius (Jacques Dubois) were particularly prominent translators of, and commentators on, Greek texts. From the 1520s Paris became the centre of an industry of translation from Greek to Latin, and, a little later, to French (usually via Latin) and of a plethora of commentary, exegesis, résumé and explanation. The new 'ancient' works were immediately influential and their teachings became the basis of a new Galenic system of medicine of which the Parisian Faculté de Médecine became the promoter, developer and vigorous defender.There was also another set of doctors in Paris, older, politically more powerful and certainly more dangerous, the Doctors of the Sorbonne - the theologians. These two Faculties regarded themselves as, and, especially during the political upheavals of the later sixteenth century effectively became, 'guardians of the public'; the Sorbonne of the public morals - in effect of religious beliefs and practices - and the Faculté de Médecine of the safety of the public and private health of the populace. From the mid-sixteenth century these hegemonies were challenged; the Sorbonne by the reformed religion and the Faculté by the rise in the numbers of iatrochemists, and their increasing popularity. The iatrochemical movement had been triggered by the writings of Paracelsus which, in turn, may have been largely influenced by yet another new ancient alchemical work, the Corpus Hermeticum which came to the West about 1460. The Doctors of the Sorbonne were strictly and aggressively Catholic and the Doctors of the Faculté were staunchly and aggressively Galenic and very largely - though not quite exclusively - Catholic also. The iatrochemists were predominantly Calvinist protestants so it was natural, convenient, and common for the Faculté to conflate their opponents' medical and religious tenets and condemn them both as medical renegades and as heretics.
But, at the end of the sixteenth century, the viciously unstable political climate of the bloody wars of religion was settling in to what would be an uneasy truce and this had profound effects on the relative power of the Faculté and of their enemies, the chemical doctors. Authorised by edicts of the Parlement, the Faculté had a monopoly over medical practice; only those it approved could practise legally in Paris and the custom of the Faculté was to refuse anyone who was not a graduate of the Parisian medical school. They particularly abhorred graduates of Montpellier (the oldest medical school in France) whose medical school they regarded as not only lax in its Galenism but dangerously tainted with religious heresy.

At the time of his accession in 1589 Henri IV was a Huguenot but, following a four-year battle against the Catholic League, he decided to re-convert permanently to Catholicism in 1593. However, Henri continued to favour his old Huguenot friends and, in 1593, he appointed as Physician in Ordinary the Calvinist iatrochemist Joseph Duschene (Quercetanus). Other Huguenot royal physicians followed, most notably Mayerne - a graduate of Montpellier - who, after being physician to Henri IV, became principal physician to James I (VI) in London. He employed chemical as well as Galenic remedies. Much as the Paris Faculté detested the nest of iatrochemical vipers in their midst, they were powerless against the royal physicians and their Huguenot and iatrochemical protégés.

This is roughly the state of affairs at the time of our thesis in 1648. Ironically, in that year appeared what would be the most influential iatrochemical text of all, the posthumous Ortus medicinae... of Joannes Baptista van Helmont.

\section{THE GALENIC SCHOOL OF THOUGHT}

The bases of the Galenic and iatrochemical schools were very different. The Galenists believed that the economy of the body was based on a system of four interacting principles, the humours, whose properties of heat, cold, dryness and moisture paralleled the four Aristotelian elements, fire, earth, air and water. Each humour shared two elemental properties: blood was hot and wet, phlegm was cold and wet, yellow bile was hot and dry and black bile was cold and dry. The proportions in which the humours were mixed in an individual produced the 'temperament'. Disease arose from a disturbance of the proportions of the humours, and the art of the physician was to recognise the disturbance and correct it. In Galenic medicine there were no diseases as separate entities, there were diseased patients. Treatment was based on the theory; the balance of the humours was readjusted principally by removing those which were in excess by bleeding, purging, induced vomiting 
and, sometimes, sweating. The theoretical basis of Galenism was, as we have seen, inherited from antiquity and, to many physicians, the ancient texts and their precepts were sacrosanct and not susceptible to alteration according to the opinions - or, importantly, to the observations - of the lesser modern successors of the unparalleled ancients.

\section{THE IATROCHEMICAL PHILOSOPHY}

The iatrochemical philosophy was triggered by the writings of Paracelsus which began to appear around 1550. In its extreme form Paracelsianism condemned Aristotle and Hippocrates as heathens and Galen as anti-Christian and emphasised the study of nature and of holy writ. But not all the iatrochemists were blind followers of Paracelsus and, indeed, many of the details of the latter's opinions were quite soon dismissed. The chemical doctors added mercury and salt to the Aristotelian elements - but (though their opponents often disregarded this distinction) these were not 'common' mercury and salt but rather their 'philosophical essences' and from this emerged a five-principled system based on mercury, sulphur, salt, water and earth. The system claimed to be based upon the 'chemical' nature of the Creation in which the physician's role was that of a divine magician. Since Nature was chemical so was man; the supposed parallelism between the macrocosm of Nature and the human microcosm suggested that disease was related to chemical disturbance and susceptible to cure by chemical manipulation. One of the curious beliefs to emerge from this type of parallelism was that of the 'power of sympathy' of which the best-known example was the 'weapon salve'. Treatment with a 'sympathetic salve' of the weapon which had caused a wound was believed to heal it. The Galenists accused the iatrochemists of using minerals and other toxins to poison their patients; to this the chemists replied that their preparation of the drugs removed their toxicity and that these de-venomised poisons cured by sympathy - poison to drive out poison. One way in which the later iatrochemists' treatments may have been of some practical advantage - as seen from a modern point of view - was that many of them, following Helmont, were vehemently opposed to the blood-letting which formed the mainstay of Galenic practice.

The iatrochemists believed, generally, that the body was controlled by an overarching governor, its archeus and, in addition, each organ had its own local archeus insitus which regulated its activities. The iatrochemical theory of the origins of disease held that diseases were of external origin and, in stark contrast to the Galenic view, had individual existence apart from the body. Each disease was induced by entry into the body of its archeus which then perverted the body's own archeus to produce a 'morbid seed' (semen morbidum) which caused the symptoms of the disease. The object of treatment was to strengthen the body's archeus and induce it to 'expel' the archeus of the infecting disease; if this was done the disease would die away and Nature's rule would be restored.

\section{THE THEORIES COMPARED}

Although the iatrochemists defended their theory as fiercely as did the Galenists, at least some of them seem to have been open - at least in principle - to tests of their beliefs by comparison of the results of different treatments. Van Helmont and, later, Starkey proposed to their antagonists contests in which groups of patients would be treated by the Galenic and the iatrochemical method and the results compared. But there is no evidence that any such 'trials' ever took place. With the passage of time, some physicians took positions between these two extreme schools of Galenism and iatrochemistry; generally they were Galenists as to their theory and much of their practice but admitted the usefulness of chemical remedies, and, in some cases pressed for their addition to the Galenic pharmacopoeia, and certainly used them themselves. Mayerne is a good example of such a practitioner. By the end of the seventeenth century probably the majority of physicians had settled in the middle and practised a sort of modified Galenism which incorporated a good deal of empiricism and many chemical remedies derived from the iatrochemical tradition. Unfortunately one iatrochemical precept did not survive, the opposition to blood-letting and purging, which continued to be practised enthusiastically.

\section{REFERENCES}

I Guillemeau C, Moreau J-B. Question cardinale a disputer aux escholles de médecine... Paris: Nicolas Boisset; 1648. French.

2 Debus AG. The French Paracelsians: the chemical challenge to medical and scientific tradition in early modern France. Cambridge: Cambridge University Press; I99I.

3 Trevor-Roper HR. Europe's physician: the various life of Sir Theodore de Mayerne. New Haven, Conn.:Yale University Press; 2006.

4 Diderot D, D'Alembert J. Encyclopédie, ou dictionnaire raisonné des sciences, des arts et des métiers. Vol I. Paris: C Briasson et al.; I75।. p. 503. French.

IML Donaldson, Honorary Librarian, RCPE (email: i.m.l.d@ed.ac.uk) 